The role of conservation agriculture in mitigation and adaptation to climate change

Uloga konzervacijske poljoprivrede u ublažavanju i prilagodbi klimatskim promjenama

Jug, D., Jug, I., Brozović, B., Vukadinović, V., Stipešević, B., Đurđević, B.

Poljoprivreda/Agriculture

ISSN: 1848-8080 (Online)

ISSN: 1330-7142 (Print)

http://dx.doi.org/10.18047/poljo.24.1.5

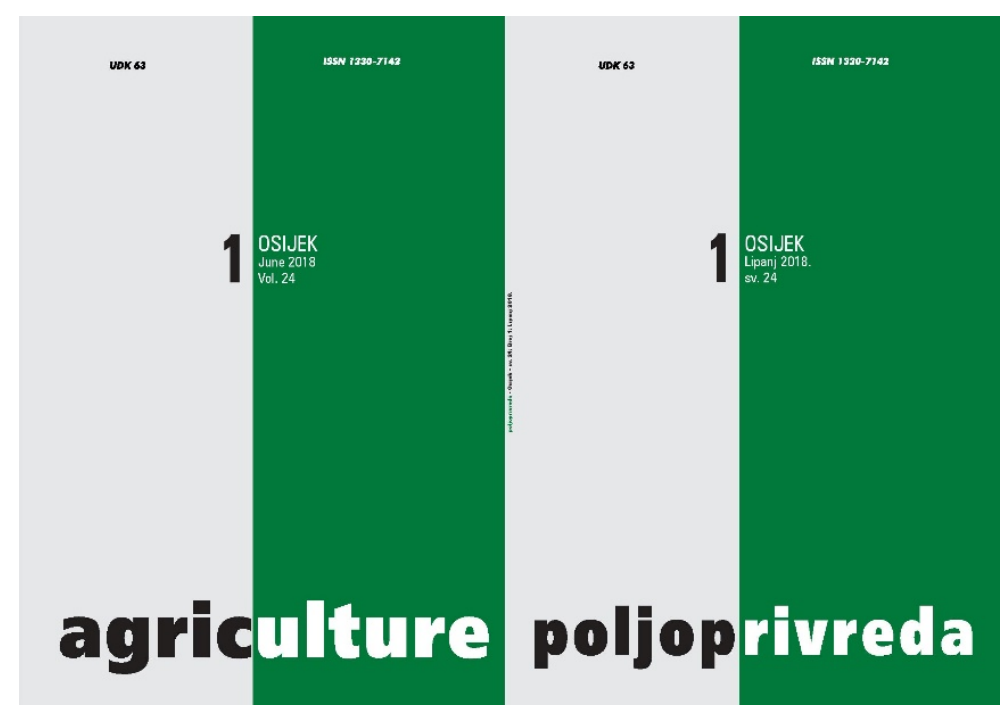

Poljoprivredni fakultet u Osijeku, Poljoprivredni institut Osijek

Faculty of Agriculture in Osijek, Agricultural Institute Osijek 


\title{
THE ROLE OF CONSERVATION AGRICULTURE IN MITIGATION AND ADAPTATION TO CLIMATE CHANGE
}

Jug, D., Jug, I., Brozović, B., Vukadinović, V., Stipešević, B., Đurđević, B.

\author{
Scientific review \\ Pregledni znanstveni članak
}

\begin{abstract}
SUMMARY
Climate change (CC) is undoubtedly induced and accelerated by human activity and can pose a serious threat to mankind by reducing food production. Significant weather aberrations in form of the uneven precipitation pattern, more frequent and intense occurrence of temperature fluctuations accompanied by changes in wind intensity and frequency, amount of clouds, intensity and quality of sunlight can be expected. Maybe the most vulnerable sector affected by CC is agriculture. So, it is important to mitigate and adapt to a new situation through different and most adaptable agricultural strategies. Accordingly, scientists, experts, politicians, decisionmakers, and others increasingly emphasize the need for further development of sustainable agricultural production, whose management will be compatible with different ecosystems (agroecosystem compliance with global ecosystems), while simultaneously restoring degraded agricultural land. One of the best solutions for sustainable agricultural production, under CC conditions, can be Conservation agriculture. Climate change is not only an abstraction, which is why one of the most important roles of conservation agriculture today is its ability to adapt and mitigate these changes. The basis of conservation agriculture production is in management set on three fundamental postulates, which contextually unify climate-soil-plant, while respecting agroecological and socio-economic differences.
\end{abstract}

Key-words: climate change, agricultural strategies, adaptation and mitigation, conservation agriculture, sustainability

\section{WEATHER AND CLIMATE RELATIONS}

According to the basic definition, the weather is short-period atmospheric conditions over the narrow area. These conditions usually last for a day or seven days maximum. The common definition of climate, on the other hand, defines it as an atmospheric condition of a specific, but wider area measured for at least 30-year period of time (Farmer, 2015). This 30-year period is most commonly used unit of measure, but it is not strictly defined, because climate can be also analysed in a mid-time period, for example of 10 years or similar (special reports for specific needs). These terms, "weather" and "climate" should be strictly distinguished because they are not the same. Weather is a term for every-change in atmosphere and climate is a term for average values of atmosphere without "every-change" effect.

Aberrations of weather and climate in a short-term period are not Climate change (CC) and this is the most common mistake in understanding the weather-climateclimate change relations.

In case when average climate is changing on a statistically significant level in a period of a few decades or longer (century or millennia), then it is possible to talk about CC. This more general definition of CC does not include anthropogenic factor or human activity from the very beginning of agriculture. Many scientists and science institutions can offer their own definitions of CC but almost all of them include direct or indirect human activity (Rahman, 2013). Accordingly, human activities over the last century are the main culprit for increasing variability of weather and climate (IPCC, 2007; DCCEE, 2012). Today two different and opposite theories (still without scientific

Prof. Dr. Danijel Jug (djug@pfos.hr), Prof. Dr. Irena Jug, Assist. Prof Bojana Brozović, Prof. Dr. Vesna Vukadinović, Prof. Dr. Bojan Stipešević, Assoc. Prof. Boris Đurđević - Josip Juraj Strossmayer University of Osijek Faculty of Agriculture in Osijek, Vladimira Preloga 1, 31000 Osijek, Croatia 
consensus) about causes and consequence of CC exist (Jug et al., 2017). According to the first theory, CC is not a novelty and it has appeared in more or less regular cyclical intervals over the last 400,000 years (Farmer, 2015) and it is usually named "natural causes" of CC. The second theory or "anthropogenic" theory of CC is supported by the majority of scientists, and according to the aforementioned, human influence makes the current climate change unique in the rapidity of the changes (IPCC, 2014a). If someone compares changes in the temperature, those occurring today are rapidly changing in comparison to the past when temperature changes were much slower even up to 30 times (Flannery, 2005). About the possible causes of $\mathrm{CC}$ there is no absolute consensus and there is also a lot of scepticism on the issue of CC, which has resulted with the creation of various conspiracy theories and unconstructive and unproductive actions. Scientific and professional, individual and collective, political and economic engagement is still insufficient to prove negative CC effect.

The phrase "global warming", or "global cooling" as a synonym, is often used instead of the term CC, which is essentially incorrect, but it can be inferred from where someone derives such misconception. The increase in average air temperature is sensitively most explicit and instrumentally visible global change. Global warming is a statistically significant increase in global air temperature resulting from natural and anthropogenic influences (over decades or longer). This phenomenon is a consequence of greenhouse effect and should be observed globally, not in the context of local and/or seasonal aberrations of meteorological elements (Figure 1).

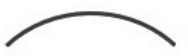

Measured data

(meteorological and climatological)

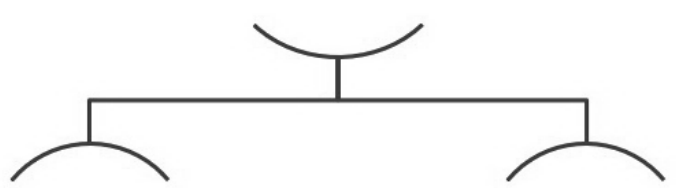

Data in range (average)

$$
\begin{aligned}
& \text { precipitation } \\
& \text { temperature } \\
& \text { wind } \\
& \text { storm } \\
& \text { sun light } \\
& \text { clouds ... }
\end{aligned}
$$

Data out of range

$$
\begin{aligned}
& \text { wetter conditions } \\
& \text { drier conditions } \\
& \text { weather aberrations } \\
& \text { climate aberrations } \\
& \text { climate changes } \\
& \ldots
\end{aligned}
$$

Figure 1. Scheme of meteorological and climatological data relations

Slika 1. Shema odnosa meteoroloških i klimatoloških podataka
According to the "logical" structure of development of CC (Figure 2), as some scientists claim, global warming is only a step towards the next occurrence on a global scale - "global cooling". Global cooling is the process of decline in the average temperature of the Earth at a statistically significant level as a direct consequence of global warming (disturbance in the atmosphere and oceanic circulation) (Jug, 2016).

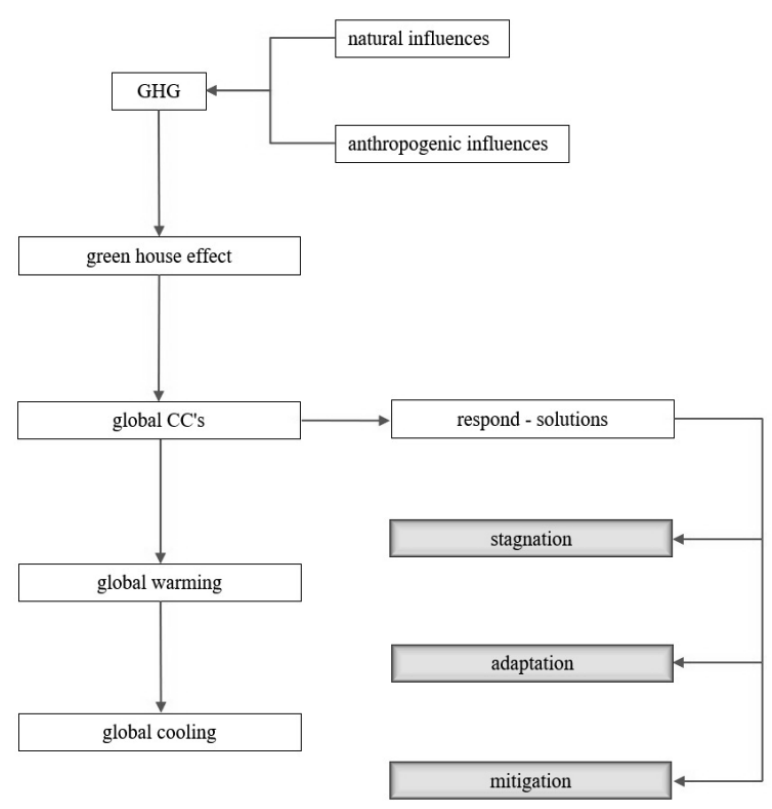

Figure 2. Flowchart of climate change

Slika 2. Dijagram toka klimatskih promjena

\section{CLIMATE CHANGE - THREATS ON A GLOBAL AND LOCAL SCALE}

On a global scale, $\mathrm{CC}$ are one of the most dangerous and degrading threats in the world whose negative influences are visible in every natural, social and economic sector. Maybe the most visible and degrading influence of CC is on the agriculture sector and on its main role, in food production for a growing population (Aune, 2012). Each climatic system consists of climatic components (atmosphere, hydrosphere, cryosphere, biosphere and pedosphere) entering into mutually very complex relations. Violation of harmony in only one of the components causes a disturbance of the whole climate system and if these disorders occur on a global scale, then one can speak about global climate disturbances or changes (Bazzaz, 1990; Goosse et al., 2010; Tan and Yew, 2015). Over the last 20 years, mankind has witnessed a more pronounced influence on adverse weather and climatic conditions, which have been more or less reflected on the economy, environment and other aspects, and perhaps most of all on agricultural production (Jug and Güttler, 2015). According to the IPCC (2014b), the global air temperature in the $20^{\text {th }}$ century has risen by $0.6^{\circ} \mathrm{C}$, which is largely attributable to human activity (Lai and Cheng, 2010; Australian Academy of Science, 2015; 
Anderson et al., 2016), but on a statistically significant level only on the short range (Stips et al., 2016). In addition, according to IPCC (2007), climate models predict an increase in the atmospheric ground temperature by an additional $1.4-5.8^{\circ} \mathrm{C}$ and increase in global precipitation ranging from $5 \%$ to $25 \%$ by the end of the $21^{\text {st }}$ century. Apart from other changes at the regional and local level, significant changes in the precipitation regime can be expected, as well as more frequent and intense occurrence of temperature and precipitation extremes, accompanied by changes in wind intensity and frequency, amount of clouds, intensity and quality of sunlight and so on. Interrelations of "usual" and "unusual" weather conditions on a global, regional and local scale are represented in Figure 3.

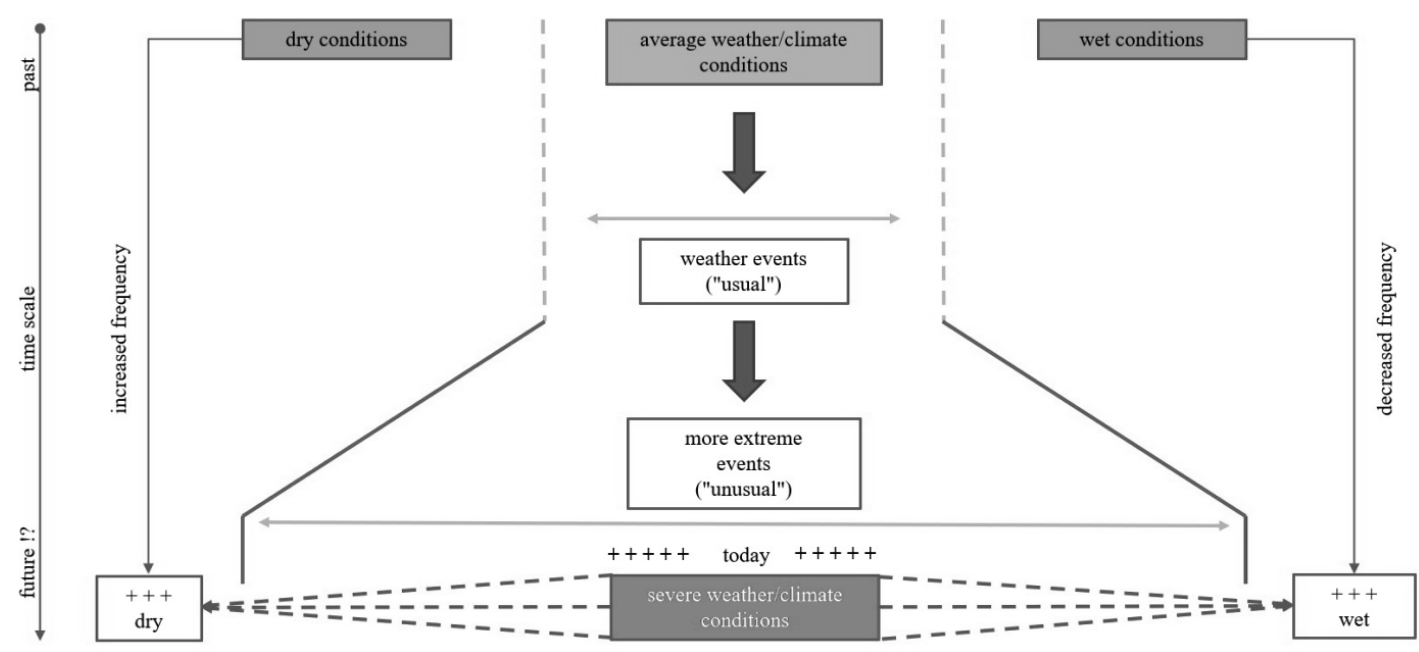

Figure 3. Relation of weather and climate in average and severe conditions

Slika 3. Odnos vremenskih i klimatskih prilika u prosječnim i ekstremnim uvjetima

The southern, south-eastern and eastern regions of Europe belong to the area of the world that is significantly vulnerable to CC (IPCC, 2001; Behrens et al., 2010; Anders et al., 2014). In these regions, a further increase in temperature of about $2^{\circ} \mathrm{C}$ in winter, and $2-3^{\circ} \mathrm{C}$ in the summer periods above the current average is predicted. It is also expected that precipitation will decrease by 5 to $15 \%$, especially in the warm period of the year and, consequently, reduce soil moisture by $15-25 \%$ (IPCC, 2001) and according to Polade et al. (2017) there will be a reduction in precipitation from $1 \%$ to $38 \%$ over Mediterranean climate regions.

\section{CAUSALITY OF AGRICULTURE AND CLIMATE CHANGE}

The main sources of greenhouse gases (as the most important elements of CC) are the following sectors: combustion of fossil fuels, industrial processes, waste disposal, deforestation and agricultural production (crop and animal production). It is estimated that agriculture is involved with at least $20 \%$ in total environmental pollution (IPCC, 2014b). According to EEA (2011, 2012), out of the total amount of greenhouse gases in the EU, about $10 \%$ came from agriculture, which is the $4^{\text {th }}$ largest emission activity, after the energy production, industry and transport. At the same time, CC have an overall global impact and the most vulnerable sectors are agriculture, water, health, forestry and biodiversity, as well as critical ecosystems (Jug and Güttler, 2015). Furthermore, there are projected changes in distribution, intensity and frequency of extreme phenomena such as heat waves and droughts. Global climate aberrations are estimated to be responsible for $32 \%$ to $39 \%$ of yield variability (Ray et al., 2015.). Agriculture is a human existential basis, and at the same time, the polluter of the environment and the victim of the polluted (degraded) environment. This paradox is a result of a specific role of agriculture: environmental polluter and food producer. The impact of direct and indirect factors on CC in the agriculture sector derives from: deforestation, desertification, loss of biodiversity, soil erosion, loss of organic matter, salinization, soil acidification, etc. (EC, 2006; Wheeler and von Braun, 2013; Gomiero, 2016; Mieszkowska, 2016). Agriculture, therefore, with its primary activity affects soil, water and air pollution, which in combination with other factors or components affects CC. On the other hand, global CC affects agriculture at the local and global level, but also in direct (physical, chemical and biological degradation) and indirect (economical, sociological, technical, technological, political and other) ways (Jug, 2016). According to 
FAO (2007), the following main consequences of CC in agriculture can be expected at the global level e.g. decrease in yield, reducing the share of agriculture in GDP, fluctuations in prices on the world market, increase in world hunger, migration and social unrests. The impact of CC on crop production is reflected through the following (Figure 4): changes in average air temperature, precipitation and its distribution, increased development of diseases, weeds and pests, soil degradation (physical, chemical and biological components), reduction of number of frost days and elongation or shortening of growing season (Lenka et al., 2015; Liu et al., 2018). The loss of biodiversity, agro-biodiversity and the spread of invasive species are among the most harmful effects of CC (Javeline et al., 2013).
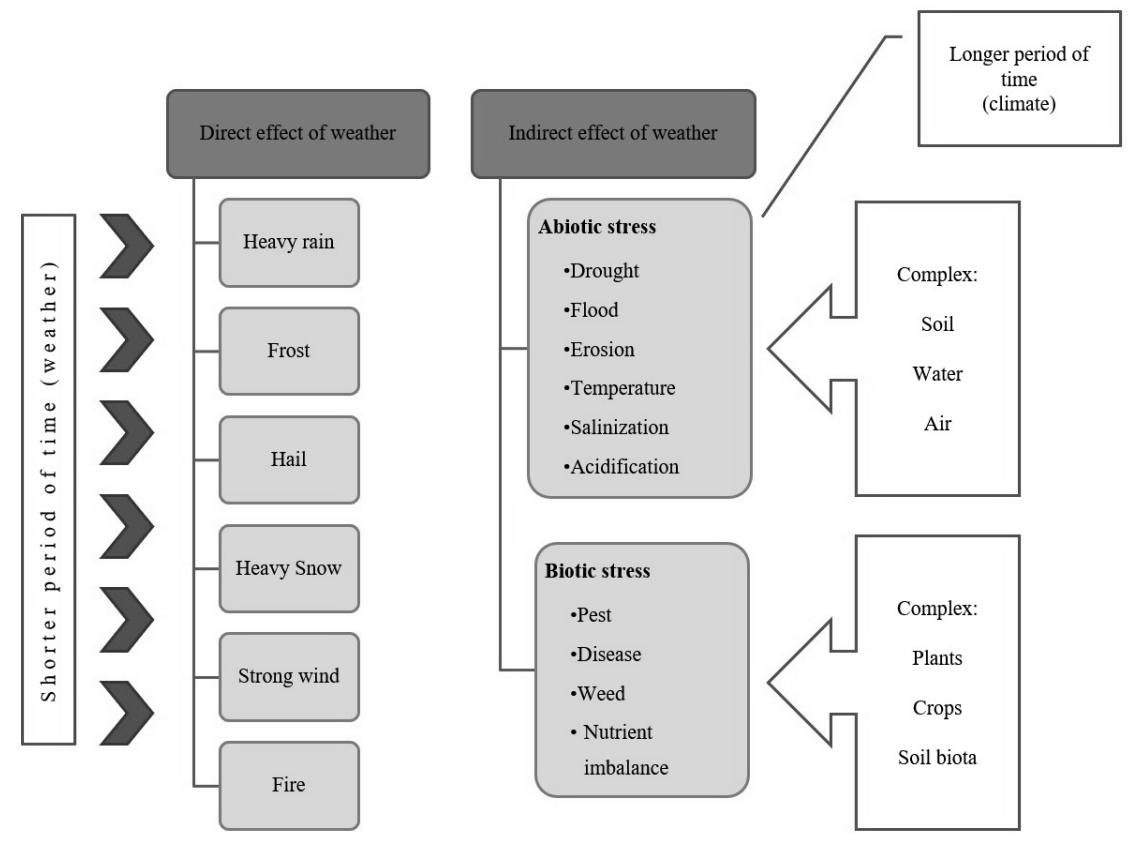

Figure 4. How weather and climate affect cropping systems?

Slika 4. Kako vremenske prilike i klima utječu na sustav uzgoja usjeva?

\section{AGRICULTURAL STRATEGIES AND POSSIBILITIES FOR ADAPTATION AND MITIGATION OF NEGATIVE INFLUENCE OF CLIMATE CHANGE}

Vulnerability of agriculture to $\mathrm{CC}$ is reflected through variability, seasonality, changes in mean precipitation and water availability, and the emergence of new pathogens and diseases (Fischlin et al., 2007) (Figure 5).

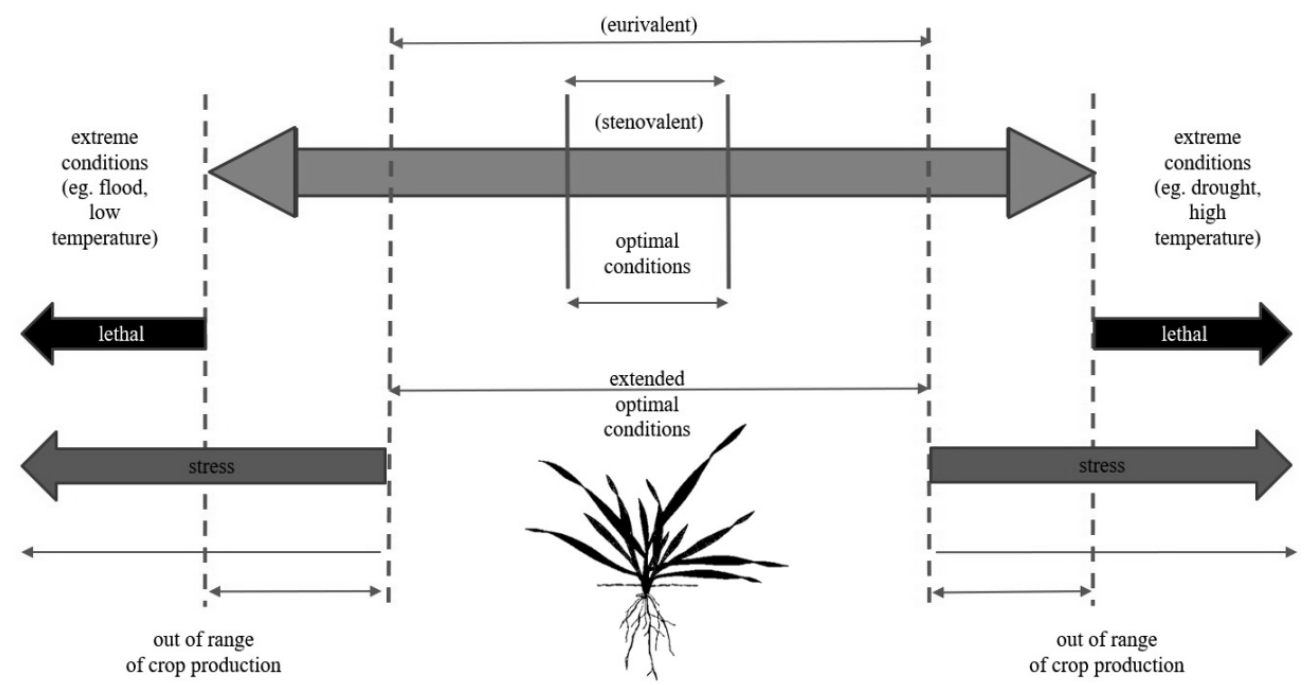

Figure 5. Intensity of agroecological factors of crop production (mainly soil, water, temperature, climate)

Slika 5. Intenzitet agroekoloških čimbenika biljne proizvodnje (uglavnom tlo, voda, temperatura, klima) 
Iglesias et al. (2007) reported possible positive effects of CC: longer growth period, faster growth times, new crops introduction in cold areas, and potential negative effects: reduced availability of water, increased thermal stress due to ambient temperatures, increase in weeds, pests and diseases, problem with flowering (absence of vernalisation), increased salinization, increased frequency of droughts, etc. Agriculture, in modern times, has tried to find best-option pathways to minimise the impacts of CC through different adaptation and mitigation strategies (Jug, 2013). These measures are implemented, on different levels respectively, by individuals, local institutions collectively or through national level policy decisions which provide finance, research and development, and knowledge transfer, and property rights or legal frameworks to enable individual or collective action (Wreford et al., 2010). Defining strategies need to take into account general conditions, which predominantly include economic and social development (knowledge, tradition, existing technology, science implementation etc.) and specific/agroecological conditions (climate, soil, water, crop, biology etc.). Basically, two main groups of primary approaches (or two different ways) for adapting cropping system to changing conditions in crop production exist today (Figure 6).

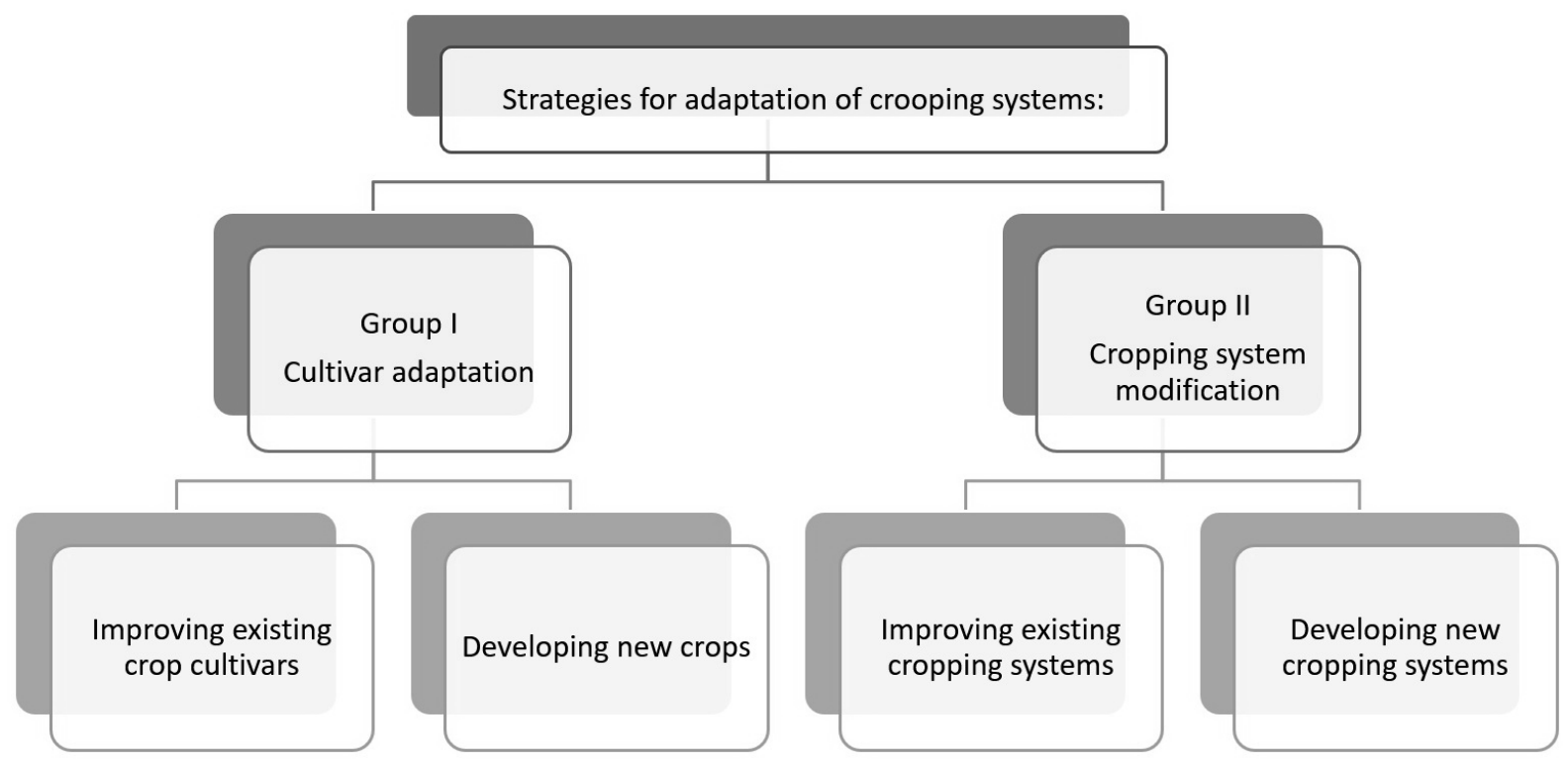

Figure 6. Main group of strategies for adaptation of cropping systems to CC

Slika 6. Glavne grupe strategija prilagodbe sustava uzgoja klimatskim promjenama

These approaches include a number of specific strategies/measures/procedures, and main measures for modification of cropping systems (Figure 6, Group II) and they are as follows:

- conservation/reduced/adapted soil tillage,

- crop rotation,

- reduced soil erosion (caused by wind and water),

- promotion of soil biogenity,

- reduction of energy consumption,

- reduction of $\mathrm{CO}_{2}$ emissions (crops and plants remain),

- prohibition of burning the crop residues,

- using crop residues for soil surface protection and preservation,

- reduction of the required number of machinery and time for tillage operations,

- controlled/limited/optimized machinery and equipment traffic,
- growing or introduction of tolerant (to modified conditions) crops (cultivars, adapting planting dates),

- intercropping crops (cover, catch and cash crops),

- integrated pest management,

- proper water management,

- weather (and climate) forecasting adaptation, etc.

\section{CONSERVATION AGRICULTURE - IS IT THE BEST SOLUTION AND RESPONSE TO CLIMATE CHANGE?}

Conservation agriculture (CA) represents one of the most significant strategies to combat CC, which has been in service to sustainability of agriculture (FAO, 2011; González-Sánchez et al., 2012; Choudhary et al., 2016; González-Sánchez et al., 2017). Conservation agriculture was originally designed in the last century (1930s), in the so called "dirty thirties" as a response 
to large-scale soil degradation (Baveye et al., 2011). CA is primarily designed for a large-scale farm, equipped with heavy and large machinery and with excessive use of herbicides. After being adopted in North and South America and Australia, CA was rapidly spread to the whole world (Palm, et al., 2014). According to Kassam et al. (2015), application of CA at a global level, in 2013, covered about $157 \mathrm{M}$ ha, which in comparison to $106 \mathrm{M}$ ha from $2008 / 09$ makes an increase of $47 \%$. Europe, with about $2.0 \mathrm{M}$ ha cropland under $\mathrm{CA}$ is on the penultimate place in comparison to the other continents. Thanks to the governments' efforts and institutions such as EC (European Commission) and, ECAF (European Conservation Agriculture Federation), from 2008/09 to 2013 CA area significantly increased, even by some $30 \%$ (Kassam et al., 2015). Further progress in acceptance of CA can be expected in the upcoming period.

"CA principles are universally applicable to all agricultural landscapes and land uses with locally adapted practices. CA enhances biodiversity and natural biological processes above and below the ground surface. Soil interventions such as mechanical soil disturbance is reduced to an absolute minimum or avoided, and external inputs such as agrochemicals and plant nutrients of mineral or organic origin are applied optimally and in ways and quantities that do not interfere with, or disrupt, the biological processes.

CA facilitates good agronomy, such as timely operations, and improves overall land husbandry for rainfed and irrigated production. Complemented by other known good practices, including the use of quality seeds, and integrated pest, nutrient, weed and water management, etc., CA is a base for sustainable agricultural production intensification. It opens increased options for integration of production sectors, such as crop-livestock integration and the integration of trees and pastures into agricultural landscapes" (FAO, 2015).

CA management is set in three basic postulates, which contextually unify climate-soil-plant, taking into account agroecological and socio-economic differences. According to FAO (2015), CA is characterised and based on three main principles as follows.

- permanent or semi-permanent soil cover (using either a previous crop residue or specifically growing a cover crop for this purpose. Usually, CA implements three categories of ground organic soil cover: $30-60 \%,>60-90 \%$ and $>90 \%$ (Derpsch, 2003), measured after the complete tillage and seeding operation. According to Derpsch (2003), soil coverage less than $15 \%$ crop residue or $550 \mathrm{~kg} \mathrm{ha}^{-1}$ of small grain residue is recognised as a Conventional tillage; coverage between 15 and $30 \%$ or 550 to $1100 \mathrm{~kg} \mathrm{ha}^{-1}$ as a Reduced tillage systems and soil tillage which leaves a minimum of $30 \%$ of crop residue on the soil surface or at least $1100 \mathrm{~kg} \mathrm{ha}^{-1}$ of small grain residue on the surface as a Conservation tillage systems),

- minimum soil disturbance through tillage (just enough to get the seed into the ground, namely less than $25 \%$ of the cropped area),

- diversification of regular crop rotations (crops grown in sequences or implementation of associations and mix of perennial or/and legume or/and non-legume crops to help combat the various biotic constraints. Rotation should involve at least 3 different group of crops: cereals, wide spaced crops and legumes; or as an example: winter wheat-maize-soybean).

CA also uses or promotes where possible or needed various management practices listed below:

- utilization of green manures/cover crops (GMCC's) to produce the residue cover,

- no burning of crop residues,

- integrated pest management,

- controlled/limited human and mechanical traffic over agricultural soils.

CA and its aforementioned basic principles are universally applicable in all agroecological conditions and landscapes with necessary adaptation to the specific local and practical conditions. Advantages of $\mathrm{CA}$, in comparison with Conventional agriculture (Christensen and Johnston, 1997; Hobbs, 2008; Busari et al., 2015; Joseph and Issahaku, 2015), can be roughly divided as:

short-term advantages: increased water infiltration and improved soil structure, lower trafficability and compaction, reduced erosion by wind and water, reduced soil water evaporation, lower water saturation/drought stress, lower fuel, mechanization and labour costs,

long-term advantages: increased soil organic matter content resulted in better soil structure, Cation Exchange Capacity (CEC), higher water holding and storage capacity, improved crop nutrition, higher and stable yields, lower costs, increased biological activity, lower weediness.

The main obstacles to the world-wide adoption of CA practices can be summarized as: insufficient knowledge (know-how, science to farmers), tradition, prejudice, inadequate policies (unrecognized specific needs for subsidies), inappropriate equipment and machinery, inappropriate ratio of land size and machinery size/price (Friedrich and Kassam, 2009; Jat et al., 2014; Farooq and Siddique, 2014; Jug et al., 2015, 2017). Complemented by other known good agronomy practices, including the use of quality seeds, and integrated pest, nutrient, weed and water management, etc., CA is a base for sustain- 
able agricultural production intensification (FA0, 2015). The yield levels of CA systems are comparable with and even higher than those under conventional tillage systems (Jug et al., 2005, 2011), with respect to all principles of sustainable agricultural production (Jug et al., 2017). The principles are reduced use of agrochemicals reflecting on the biological component of soil and water quality (Laurent et al., 2011), carbon sequestration rate aid ranging from 0.2 to $1.0 \mathrm{t} \mathrm{ha}^{-1} \mathrm{yr}^{-1}$ (Corsi et al., 2012; Kertész and Madarász, 2014; Srinivasarao et al., 2014), depending on the agroecological conditions and soil management methods (González-Sánchez et al., 2017), reducing the workload by $50 \%$, which allows producers to save time, reduce fuel costs and machinery (Saturnino and Landers, 2002; Crabtree, 2010; Lindvall and Sonntag, 2010). Soil organic carbon can be a source of greenhouse gas emission through the formation of $\mathrm{CO}_{2}, \mathrm{CH}_{4}$ and $\mathrm{N}_{2} \mathrm{O}$ and by applying the $\mathrm{CA}$ principle, the concentration of greenhouse gases is reduced, thereby affecting the mitigation of CC. Changes induced by CA related to the $\mathrm{C}$ dynamics in the soil, lead directly to an increase in soil $C$. Also, drastic reduction in the amount of tillage operation of the soil reduces $\mathrm{CO}_{2}$ emissions and reduces mineralization process of the organic matter (Krauss et al., 2017). CA increases the vertical stratification of the soil organic matter and this stratification is taken as a quality recovery index of agricultural land degraded by soil tillage (Franzluebbers, 2002; Moreno et al, 2005; Blanco-Canqui and Lal, 2007). The beneficial effects on the environment derived from CA have been widely studied by scientist for decades, which are pertaining to erosion, in relation to the water use (Blanco-Canqui and Lal, 2007), regarding the biodiversity improvements and the fight against CC (González-Sánchez et al., 2012; Henneron et al., 2015) and changes in agricultural model due to problems caused by soil degradation (Van-Camp et al., 2004). CA represents the core components of a new alternative paradigm for the $21^{\text {st }}$ century and calls for a fundamental change in a production system thinking.

Main reasons for the adoption of CA can be summarized as follows: (1) better farm economy (2) flexible agrotechnical possibilities for sowing, fertilizer application and weed control; (3) yield increases and greater yield stability (as long-term effect); (4) soil protection (5) greater nutrient efficiency. Briefly, CA offers a number of benefits to the producers, the society and the environment, but most importantly, its benefits are in a domain of efficient possibilities to combat CC through adaptation and mitigation strategies.

\section{CONCLUSION}

Since climate change (CC) is not restricted by narrow local or national borders or even wide borders on regional or global scale and since agriculture is extremely vulnerable to them, a common action to find adequate and effective measures or strategies to face them is an imperative. For successful approach to the adaptation and mitigation processes, it is neces- sary to create adequate and useful strategies which will be developed through strong regional cooperation of experts with professional competence to reach the satisfying results in relation to the regional specificity of economic and social development, agroecological conditions, crop production and environment. It is important to emphasise that time to mitigate CC is expiring and the only remaining solution/option is the adaptation that must be based on the scientific facts. Conservation agriculture attracts more and more attention from numerous scientists around the world by offering a solution to the problems associated with CC.

\section{REFERENCES}

1. Anders, I., Stagl, J., Auer, I., \& Pavlik, D. (2014). Climate change in central and eastern Europe. In Managing Protected Areas in Central and Eastern Europe Under Climate Change (pp. 17-30). Springer, Dordrecht. https://link.springer.com/chapter/10.1007/978-94-007-7960-0_2

2. Anderson, T. R., Hawkins, E., \& Jones, P. D. (2016). C02, the greenhouse effect and global warming: from the pioneering work of Arrhenius and Callendar to today's Earth System Models. Endeavour, 40(3), 178-187. https:// dx.doi.org/10.1016/j.endeavour.2016.07.002

3. Aune, J. B. (2012). Conventional, organic and conservation agriculture: production and environmental impact. In Agroecology and strategies for climate change (pp. 149-165). Springer Netherlands. https://doi. org/10.1007/978-94-007-1905-7_7

4. Australian Academy of Science (2015). The science of climate change: Questions and answers. Australian Academy of Science, Canberra, 2015, 44.

5. Baveye, P. C., Rangel, D., Jacobson, A. R., Laba, M., Darnault, C., Otten, W., ... \& Camargo, F. A. (2011). From dust bowl to dust bowl: soils are still very much a frontier of science. Soil Science Society of America Journal, 75(6), 2037-2048.

6. Bazzaz, F. A. (1990). The response of natural ecosystems to the rising global $\mathrm{CO}_{2}$ levels. Annual Review of Ecology and Systematics, 21(1), 167-196.

7. Behrens, A., Georgiev, A. \& Carraro, M. (2010). Future Impacts of Climate Change across Europe. CEPS Working Document No. 324/February 2010.

http://aei.pitt.edu/14586/1/WD 324 Behrens, Georgiev_\&_Carraro_final_updated_(1).pdf

8. Blanco-Canqui, H. \& Lal, R. (2007). Impacts on long-term wheat strow management on soil hydraulic properties under no tillage. Soil Science Society of America Journal, 72, 693-701.

9. Busari, M. A., Kukal, S. S., Kaur, A., Bhatt, R., \& Dulazi, A. A. (2015). Conservation tillage impacts on soil, crop and the environment. International Soil and Water Conservation Research, 3(2), 119-129. https:// doi.org/10.1016/j.iswcr.2015.05.002

10. Choudhary M., Ghasal, P. C., Kumar, S. R. P., Yadav, S. S., Meena, V. S. \& Bisht, J. K. (2016). Conservation Agriculture and Climate Change: An Overview. In: 
Bisht J., Meena V., Mishra P., Pattanayak A. (eds) Conservation Agriculture. Springer, Singapore. https://doi.org/10.1007/978-981-10-2558-7_1

11. Christensen, B. T., \& Johnston, A. E. (1997). Chapter 18 Soil organic matter and soil quality-lessons learned from long-term experiments at Askov and Rothamsted. Developments in Soil Science, 25, 399-430. https://doi. org/10.1016/S0166-2481(97)80045-1

12. Corsi, S., Friedrich, T., Kassam, A., Pisante, M. \& de Moraes Sà, J. (2012). Soil organic carbon accumulation and greenhouse gas emission reductions from Conservation Agriculture: A literature review. Integrated Crop Management, 16, FA0, Rome, Italy.

13. Crabtree, B. (2010). In search for sustainability in dryland agriculture. Crabtree Agricultural Consulting, Australia.

14. DCCEE (Department of Climate Change and Energy Efficiency) (2012). Climate Change in a nutshell. Australian Government, Canberra. http://www.climatechange.gov.au/en/climate-change.aspx

15. Derpsch, R. (2003). Conservation tillage, no-tillage and related technologies. In Conservation Agriculture (pp. 181190). Springer, Dordrecht. https://doi.org/10.1007/97894-017-1143-2_23

16. EC (Commission of the European Communities) (2006). Thematic Strategy for Soil Protection. COM(2006)231 final, Brussels. http://eur-lex.europa.eu/legal-content/ EN/TXT/PDF/?uri =CELEX:52006DC0231\&from =EN

17. EEA (European Environment Agency) (2011). Technical Report N13/2012. Approximated EU.

18. EEA (European Environment Agency) (2012). Climate change, impact and vulnerability in Europe 2012 Inform.

19. FAO (2007). Adaptation to climate change in agriculture, forestry and fisheries: Perspective, framework and priorities. Report of the FAO Inter departmental Working Group on Climate Change. Rome.

20. FAO (2011). Conservation Agriculture Website. Available in: http://www.fao.org/ag/ca/1a.html (20.02.18)

21. FAO (2015): The main principles of conservation agriculture. http://www.fao.org/ag/ca/1b.html

22. Farmer, G. T. (2015). Modern Climate Change Science. An Overview of Today's Climate Change Science. Springer. https://doi.org/10.1007/978-3-319-09222-5

23. Farooq, M. \& Siddique, K. H. M. (eds.) (2014). Conservation Agriculture. Springer International, Switzerland.

24. Fischlin, A., Midgley, G. F., Price, J. T., Leemans, R., Gopal, B., Turley, C., Rounsevell, M. D. A., Dube, O. P., Tarazona, J. \& Velichko, A. A. (2007). Ecosystems, their properties, goods, and services. Climate Change 2007: Impacts, Adaptation and Vulnerability. Contribution of Working Group II to the Fourth Assessment Report of the Intergovernmental Panel on Climate Change, M.L. Parry, O.F. Canziani, J.P. Palutikof, P.J. van der Linden and C.E. Hanson, Eds., Cambridge University Press, Cambridge, 211-272.

25. Flannery, T. (2005). The Weather Makers: The History and Future Impact of Climate Change. Algoritam, Zagreb.

26. Franzluebbers, A. J. (2002). Soil organic matter stratification ratio as an indicator of soil quality. Soil and
Tillage Research, 66(2), 95-106. https://doi.org/10.1016/ S0167-1987(02)00018-1

27. Friedrich, T. \& Kassam, A. H. (2009). Adoption of Conservation Agriculture Technologies: Constraints and Opportunities. IV World Congress on Conservation Agriculture. 4-7 February 2009, New Delhi, India.

28. Gomiero, T. (2016). Soil Degradation, Land Scarcity and Food Security: Reviewing a Complex Challenge. Sustainability, 8(3), 281. https://doi.org/10.3390/ su8030281

29. González-Sánchez, E. J., Ordóñez-Fernández, R. Carbonell-Bojollo, R., Veroz-González, 0. \& Gil-Ribes, J. A. (2012). Meta-analysis on atmospheric carbon capture in Spain through the use of conservation agriculture. Soil and Tillage Research 122, 52-60. https:// doi.org/10.1016/j.still.2012.03.001

30. González-Sánchez, E.J., Moreno-García, M., Kassam, A., Holgado-Cabrera, A., Triviño-Tarradas, P., CarbonellBojollo, R., Pisante, M., Veroz-González, 0. \& Basch, G. (2017). Conservation Agriculture: Making Climate Change Mitigation and Adaptation Real in Europe. ECAF, Brussels. http://www.ecaf.org/inaction/news/item/60a-major-new-research-study-in-favour-of conservationagriculture (16.03.18)

31. Goosse, H., Barriat, P. Y., Lefebvre, W. M., Loutre, F. \& Zunz, V. (2010). Introduction to climate dynamics and climate modelling, $\mathrm{Ch}$. 1. Description of the climate system and its components (pp. 1-24). http://www.climate.be/ textbook

32. Henneron, L. Bernard, L., Hedde, M., Pelosi, C., Villenave, C. Chenu, C., Bertrand, M., Girardin, C. \& Blanchart, E. (2015). Fourteen years of evidence for positive effects of conservation agriculture and organic farming on soil life. Agronomy for Sustainable Development, 35(1), 169-181. https://doi.org/10.1007/s13593-014-0215-8

33. Hobbs, P. R., Sayre, K., \& Gupta, R. (2008). The role of conservation agriculture in sustainable agriculture. Philosophical Transactions of the Royal Society of London B: Biological Sciences, 363(1491), 543-555. https://doi.org/10.1098/rstb.2007.2169

34. Iglesias, A., Garrote, L., Flores, F. \& Moneo, M. (2007). Challenges to manage the risk of water scarcity and climate change in the Mediterranean. Water Resources Management, 21(5), 775-788. https://doi.org/10.1007/ s11269-006-9111-6

35. IPCC (Intergovernmental Panel on Climate Change) (2001). Climate Change. IPCC Third Assessment Report. The Scientific Basis. Workbook.

36. IPCC (Intergovernmental Panel on Climate Change) (2007). Climate Change: The Physical Science Basis. In Solomon, S.D., et al., eds.: Contribution of Working Group I to the Fourth Assessment Report of the Intergovernmental Panel on Climate Change. Cambridge University Press, Cambridge.

37. IPCC (Intergovernmental Panel on Climate Change) (2014a) IPCC Fifth Assessment report: Climate Change 2014: Impacts, Adaptation, and Vulnerability, pp 113.-142.

38. IPCC (Intergovernmental Panel on Climate Change) (2014b). “Climate Change 2014: Impacts, Adaptation, and Vulnerability. Working Group II Contribution to the 
IPCC 5th Assessment Report - Changes to the Underlying Scientific/Technical Assessment", Ch 23-Europe.

39. Jat, R. A., Sahrawat, K. L. \& Kassam, A. H. (eds) (2014). Conservation Agriculture: Global Prospects and Challenges. CABI, Wallingford. 393.

40. Javeline, D., Hellmann, J. J., Cornejo, R. C. \& Shufeldt G. (2013). Expert Opinion on Climate Change and Threats to Biodiversity. BioScience, 63(8), 666-673. https://doi. org/10.1525/bio.2013.63.8.9

41. Joseph, K. X., \& Issahaku, Z. (2015). Effects of soil conservation technologies in improving soil productivity in northern Ghana. Journal of Soil Science and Environmental Management, 6(6), 158-167. https://doi. org/10.5897/JSSEM15.0490

42. Jug, D., Blažinkov, M., Redžepović, S., Jug, I. \& Stipešević, B. (2005). Effects of different soil tillage systems on nodulation and yield of soybean. Poljoprivreda, 11 (2), 38-43. https://hrcak.srce.hr/11943

43. Jug, I., Jug, D., Sabo, M., Stipesevic, B. \& Stosic, M. (2011). Winter wheat yield and yield components as affected by soil tillage systems. Turkish Journal of Agriculture and Forestry, 35(1), 1-7. https://doi. org/10.3906/tar-0909-376

44. Jug, D. (2013). Current Trends in Agronomy for Sustainable Agriculture. Summer School / S. Duškova (ur.). Brno, Czech Republic, Mendel University in Brno, Faculty of Agronomy, pp. 158-166.

45. Jug, D., Birkás, M. \& Kisić, I. (2015). Soil tillage in agroecology framework. University textbook (In Croatian). Croatian Soil Tillage Research Organization, Osijek, Croatia, ISBN: 978-953-7871-48-2.

46. Jug, D. \& Güttler, I. (2015). GEWEX Workshop on the Climate System of the Pannonian Basin. Osijek, Croatia, 9-11 November.

47. Jug, D. (2016). Agriculture - A Stakeholder in the Causality of Climate Change. Ephemerides theologicae Diacovenses (In Croatian), 24 (1), 65-79. https://hrcak.srce.hr/157299

48. Jug D., Jug I., Vukadinović V., Đurđević B., Stipešević B. \& Brozović B. (2017). Conservation soil tillage as a measure for climate change mitigation. University textbook (In Croatian). Croatian Soil Tillage Research Organization, Osijek, Croatia. ISBN: 978-953-7871-61-1.

49. Kassam, A., Friedrich, T., Derpsch, R. \& Kienzle, J. (2015). Overview of the Worldwide Spread of Conservation Agriculture

50. Kertész, Á. \& Madarász, B. (2014). Conservation Agriculture in Europe. International Soil and Water Conservation Research, 2(1), 91-96. https://doi. org/10.1016/S2095-6339(15)30016-2

51. Krauss, M., Ruser, R., Müller, T., Hansen, S., Mäder, P. \& Gattinger, A. (2017). Impact of reduced tillage on greenhouse gas emissions and soil carbon stocks in an organic grass-clover ley - winter wheat cropping sequence. Agriculture, Ecosystems \& Environment, 239, 324-333. https://doi.org/10.1016/j.agee.2017.01.029

52. Lai, L. W. \& Cheng, W. L. (2010). Air temperature change due to human activities in Taiwan for the past century. International Journal of Climatology, 30(3), 432-444. https://doi.org/10.1002/joc.1898
53. Laurent, F., Leturcq, G., Mello, I., Corbonnois, J. \& Verdum, R. (2011). La diffusion du semis direct au Brésil, diversité des pratiques et logiques territoriales: l'exemple de la région d'Itaipu au Paraná. https://doi. org/10.4000/confins.7143

54. Lenka, S., Lenka, N. K., Sejian, V. \& Mohanty, M. (2015). Contribution of Agriculture Sector to Climate Change. In: Sejian V., Gaughan J., Baumgard L., Prasad C. (eds) Climate Change Impact on Livestock: Adaptation and Mitigation. Springer, New Delhi. https://doi. org/10.1007/978-81-322-2265-1_3

55. Lindwall, C. W. \& Sonntag, B. (2010). Landscape Transformed: The History of Conservation Tillage and Direct Seeding, Knowledge Impact in Society, Saskatoon, University of Saskatchewan.

56. Liu, O., Piao, S., Janssens, I.A., Fu, Y., Peng, S., Lian, X., Ciais, P., Myneni, R.B., Peñuelas, J. \& Wang, T. (2018): Extension of the growing season increases vegetation exposure to frost. Nature Communications, 9(1), 426. https://doi.org/10.1038/s41467-017-02690-y

57. Mieszkowska, N. (2016). Intertidal indicators of Climate and Global Change. In T. M., Letcher (Ed.), Climate change: observed impacts on planet Earth, Vol. 2, pp 307-322, Elsevier B.V.

58. Moreno, F., Murillo, J. M., Madejón, E., Girón, I. F. \& Pelegrín, F. (2005). Laboreo de conservacíon: efectos a largo plazo sobre la calidad del suelo. En conreso Internacional sobre Agricultura de Conservación: El reto de la agricultura, el medio ambiente, la energía y la nueva Politica Agraria Comúnn. Libro de Actas: 515-520. AEAC.SV.ECAF, Diputacíon de Córdoba. Córdoba.

59. Palm, C., Blanco-Canqui, H., DeClerck, F., Gatere, L. \& Grace, P. (2014). Conservation agriculture and ecosystem services: An overview. Agriculture, Ecosystems and Environment, 187, 87-105. doi.org/10.1016/j. agee.2013.10.010

60. Polade, S. D., Gershunov, A., Cayan, D. R., Michael Dettinger, D. \& Pierce, D. W. (2017). Precipitation in a warming world: Assessing projected hydro-climate changes in California and other Mediterranean climate regions. Scientific Reports, 7, Article number: 10783. https://doi.org/10.1038/s41598-017-11285-y

61. Rahman, M. I. (2013). Climate change: a theoretical review. Interdisciplinary Description of Complex Systems, 11(1), 1-13. https://doi.org/10.7906/indecs.11.1.1

62. Ray, D. K., Gerber, J. S., MacDonald, G. K. \& West, P. C. (2015). Climate variation explanes a third of global crop yield variability. Nature Communications, 6, Article number: 5989. https://doi.org/10.1038/nciomms6989

63. Saturnino, H. M. \& Landers, J. N. (2002). The Environment and Zero Tillage, APDC-FA0, Brasilia, Brazil, UDC.

64. Srinivasarao C., Lal R., Kundu S., Thakur P. (2015). Conservation Agriculture and Soil Carbon Sequestration. In: Farooq M., Siddique K. (eds) Conservation Agriculture. Springer, Cham. https://doi.org/10.1007/978-3-31911620-4_19

65. Stips, A., Macias, D., Coughlan, C., Garcia-Gorriz E. \& Liang X. S. (2016). On the causal structure between CO2 and global temperature. Scientific Reports Vol. 6, Article number: 21691. https://doi.org/10.1038/srep21691 
66. Tan, X. \& Yew T. (2015). Contribution of human and climate change impacts to changes in streamflow of Canada. Scientific Reports, 5, Article number: 17767. https://doi.org/10.1038/srep17767

67. Van-Camp, L., Bujarrabal, B., Gentile, A. R., Jones, R. J. A., Montanarella, L. \& Olazabal, S. K. (2004). Reports of the Technical Working Groups Established under the Thematic Strategy for Soil Protection. EUR 21319
EN/1, Office for Official Publications of the European Communities, Luxembourg.

68. Wheeler, T., \& Von Braun, J. (2013). Climate change impacts on global food security. Science, 341(6145), 508-513. https://doi.org/10.1126/science.1239402

69. Wreford, A., Moran, D. \& Adger, N. (2010). Climate Change and Agriculture. Impacts, Adaptation and Mitigation. OECD.

\section{ULOGA KONZERVACIJSKE POLJOPRIVREDE U UBLAŽAVANJU I PRILAGODBI KLIMATSKIM PROMJENAMA}

\section{SAŽETAK}

Klimatske su promjene nesumnjivo potaknute $i$ ubrzane ljudskom aktivnošću i mogu predstavljati ozbiljnu prijetnju čovječanstvu smanjenjem proizvodnje hrane. U budućnosti se mogu očekivati značajna odstupanja vremenskih prilika u obliku neujednačenih oborinskih obrazaca, češćih $i$ intenzivnijih temperaturnih oscilacija, promjene intenziteta i učestalosti vjetra, količine oblaka, intenziteta i kvalitete sunčeve svjetlosti. Poljoprivreda se ubraja u najranjivije sektore koji su pod izravnim utjecajem klimatskih promjena, zbog čega je iznimno bitno ublažiti njïhov utjecaj i prilagoditi se novonastaloj situaciji primjenom različitih poljoprivrednih strategija. Prema tome, znanstvenici, stručnjaci, političari, donositelji odluka $i$ drugi akteri sve više naglašavaju potrebu daljnjega razvoja održive poljoprivredne proizvodnje, čije će upravljanje biti kompatibilno s različitim ekosustavima (usklađenost agroekosustava s globalnim ekosustavima), uz istovremeno obnavljanje degradiranoga poljoprivrednoga zemljišta. Jedno od najboljih rješenja iz domene održive poljoprivredne proizvodnje, u uvjetima klimatskih promjena, može predstavljati konzervacijska poljoprivreda. Klimatske promjene nisu samo apstrakcija, zbog čega je jedna od najvažnijih uloga konzervacijske poljoprivrede u današnje vrijeme upravo njezina sposobnost prilagodbe i ublažavanja tim promjenama. Temelj konzervacijske poljoprivredne proizvodnje postavljen je na njena tri osnovna postulata, koji kontekstualno ujedinjuju klimu, tlo i biljku, uz uvažavanje agroekoloških i društveno-ekonomskih razlika.

Ključne riječi: klimatske promjene, poljoprivredne strategije, prilagodba $i$ ublažavanje, konzervacijska poljoprivreda, održivost

(Received on 16 April 2018; accepted on 15 May 2018 - Primljeno 16. travnja 2018.; prihvaćeno 15. svibnja 2018.) 